IFAS Extension

\title{
FINANCIAL RECORDKEEPING: ORGANIZING YOUR FINANCIAL LIFE ${ }^{1}$
}

\author{
Selena Garrison, Michael Gutter, Julie England, Jo Turner and Nayda Torres ${ }^{2}$
}

BETWEEN taxes, investments, budgets, and loans, consumers have an enormous amount of information to keep track of. In fact, since many of these records are in paper form, keeping copies of them can require a considerable amount of time, organization, and space.

Not having a system for keeping track of financial papers may cause you to misplace bills, lose receipts, warranties and rebate forms as well waste time looking for needed documents. In addition to wasted time and increased stress, this may lead to late or missed payments that cost money due to late fees and interest. Delayed payments may lower your credit score which in turn may raise the interest rate on loans and credit cards.

There are many relevant questions regarding this topic. How long should you hold on to financial records? One year? Three years? Seven Years? Does the type of financial record matter? Is there a difference for everyday receipts, paystubs, banks records, bills, and homeownership papers? Organizing your financial life can be very confusing, especially if you do not know what to throw away, what to keep, and how long to keep it. This publication will address the following questions. What records to keep and why? How long do we keep them for? Where should we keep them?

\section{FINANCIAL DOCUMENTS}

\section{TAX RECORDS}

In general, tax records, including returns, relevant canceled checks or receipts, and records of deduction taken, should be kept for approximately 3-7 years.

For your tax returns, the IRS has 3 years from the filing date to audit them. You will want to keep these returns in case an audit occurs. If you find a mistake on your return, you also have three years from the filing date to submit an amended return. This usually would happen if you should have received a refund on something that you failed to claim such as alimony payments, charitable contributions, education expenses, retirement contributions, or mortgage interest. If the IRS thinks that you underreported your gross income by at least $25 \%$, it has six years to challenge your return. If you failed to file a tax return, or if you filed a fraudulent return, there is no time limit required for the IRS to seek payment or punishment.

1. This document is Fact Sheet FCS5205, one in a series of the Department of Family, Youth and Community Sciences, Florida Cooperative Extension Service, Institute of Food and Agricultural Sciences, University of Florida. First published July 2001 as Show Me the Money, Lesson 2. Revised: October 2009. Please visit the EDIS Web site at http://edis.ifas.ufl.edu.

2. Written by Selena Garrison, graduate student; Michael S. Gutter, assistant professor and family financial management specialist; Julie England, extension agent for Lake County; Jo Turner, professor emeritus; Nayda Torres, professor and chair; Department of Family, Youth and Community Sciences; Institute of Food and Agricultural Sciences; University of Florida; Gainesville 32611. 


\section{IRA CONTRIBUTIONS}

If you made a contribution to an IRA that was not tax deductible, you should keep the records permanently to prove that you already paid taxes on that money when it comes time for you to withdraw it. If it was deductible, you will still want to have this record in case of an audit by the IRS or in case you have to communicate with the financial institution that your IRA is with.

\section{Retirement/Savings Plan Statements}

For these accounts, such as $401(\mathrm{k}), 403(\mathrm{~b})$, IRAs, or other savings plans, you should keep the quarterly summaries until you receive the annual summary. If the quarterly summaries match up to the annual summaries, the quarterly summaries can be shredded. Annual summaries should be kept until you retire or close the account.

\section{BROKERAge StATEMENTS}

In order to prove that you have capital gains or losses at tax time, you will need the purchase or sales slips from your broker/dealer or mutual fund company(ies). These statements will be used to determine the cost basis from which any gain or loss is determined. The timing of these transactions will also impact the rate at which any gains are taxed.

\section{BILLS AND RECEIPTS}

Most bills can be held for a year or less. Usually, if the bill has been paid in full and the money has cleared your account, you can shred the bill. For large purchases or purchases that have warrantees, however, receipts should be kept in a file to prove their value in case of loss, theft, or damage. These receipts include purchases such as jewelry, appliances, collectibles, cars, antiques, computers, and other valuables.

\section{BANK RECORDS}

Go through your bank records each year and keep anything related to taxes, business expenses, home improvements, or mortgage payments. Anything that is not of long term importance can be shredded.

\section{CAsh/Debit Card/Credit Card Receipts and Statements}

Keep all receipts until you get your monthly account statements. If your statement matches up with your receipts, the receipts can be shredded. If tax-related expenses are documented on the receipts, they should be kept for seven years. Again, for purchases such as jewelry, appliances, collectibles, cars, antiques, computers, and other valuables, receipts should be kept in case of loss, theft, or damage.

\section{PAYCHECK StUBS}

Check stubs should be kept until you receive your W-2 at the end of the year. If the check stubs and the W-2 match up, the stubs can be shredded. If they do not match up, you should notify your employer and demand a correct $W$ 2 , known as a $\mathrm{W}-2 \mathrm{c}$.

\section{NAMES/ADDRESSES OF FINANCIAL INSTITUTIONS AND LOCATION OF SAVINGS/CHECK BOOKS}

In the case of an emergency or disaster, you will want to have these records in order to access your money.

\section{HOMEOWNER RECORDS}

All records that document the purchase price and the cost of all permanent improvements (i.e. remodeling, additions, installations) should be kept. You should also keep records of expenses such as legal fees and real estate agent commissions associated with buying or selling your property for at least six years.

Any improvements you make to your home, as well as expenses in selling it, increase your cost basis. This leads to lower capital gains tax when you sell your home. 


\section{RECORDS OF OUTSTANDING DEBTS/NOTES/ MORTGAGES AND NAMES/ADDRESSES OF LENDERS}

In the case of a financial emergency, all of these will be important. You will want to have the contact information for your lenders, because it is very important to communicate with them throughout any time where you may not be able to pay your debts. They are much more likely to work with you BEFORE you get behind on your payments than after.

When you pay off a debt, you should always save a record of this; especially if it has been sent to collections at some point. These debts can be re-packaged, they can be re-sold, and they could re-appear on your credit history. If they re-appear you would need to be disputed with the credit bureau or another collection agency that has purchased these already-paid debts.

\section{Personal Documents}

The following personal documents should be kept safe and secure permanently and at all times. In the case of disaster, emergency, or identity theft, these will be of vital importance.

\section{Certificates of Birth, Death, Marriage, or Divorce}

These documents are very important and should be kept safe at all times. If all else is lost, these documents, as well as social security papers and picture ID, will be needed to establish your identity and regain access to your financial accounts. Should any of these be lost, contact your appropriate community location (usually the courthouse) for replacements.

\section{SOCIAL SECURITY PAPERS}

These are the primary documentation of your citizenship in the United States of America. It is vital that these be kept safe. Should you lose your Social Security card, contact your local Social Security office immediately for a replacement.

\section{PASSPORTS}

All current, valid passports should be kept safe in order to establish your identity when international travel is required. If you decide to dispose of expired passports, make sure to do so appropriately by shredding them or cutting them up before throwing them away.

\section{NAMES/ADDRESSES/PHONE NUMBERS OF FINANCIAL/BUSINESS/PERSONAL/LEGAL ADVISORS}

In the case of a financial emergency, all of these will be important. You should keep the contact information for any advisors that you have in a safe place so that you can get in touch with them in the case of an emergency.

\section{COPIES OF CRITICAL LETTERS, LETTERS OF APPOINTMENT OR RESIGNATION, LEGAL NOTIFICATIONS}

These documents should be kept as proof of appointment, resignation, or notification just in case they need to be used for legal matters in the future.

Table 1 summarizes how long to keep certain records and recommended places for storing them. Note that when you dispose of any of these records, you should shred these documents. Most of these contain information that someone could use to steal your identity. Thus, you should take care when disposing of them. 
TABLE 1. SUMMARY OF TIMELINE AND LOCATION FOR FINANCIAL AND PERSONAL DOCUMENTS

\begin{tabular}{|c|c|c|}
\hline \multicolumn{3}{|c|}{ FINANCIAL DOCUMENTS } \\
\hline Type of Record & How long to keep & Where to Keep Them \\
\hline Tax Documents & 3 to 7 years & Filing Cabinet \\
\hline IRA Contributions & Permanently & Filing cabinet \\
\hline Retirement/Savings Plan Statements & 1 year to Permanently & Filing Cabinet \\
\hline Brokerage Statements & Until securities are sold & Filing Cabinet \\
\hline Bills and Receipts & 1 year to Permanently & Filing Cabinet \\
\hline Bank Records & 1 year to Permanently & Filing Cabinet \\
\hline $\begin{array}{c}\text { Cash/Debit Card/Credit Card Receipts } \\
\text { and Statements }\end{array}$ & From 45 days to 7 years & Filing Cabinet \\
\hline Final Statements & At least 7 years from the payoff & Filing Cabinet \\
\hline Check Stubs & 1 year & Filing Cabinet \\
\hline $\begin{array}{l}\text { Names and addresses of financial } \\
\text { institutions where checking and savings } \\
\text { accounts are kept and location of } \\
\text { savings and check books. }\end{array}$ & Permanently & Fireproof Box or Safe Deposit Box \\
\hline Homeowner Records & 6 years to Permanently & $\begin{array}{l}\text { Fireproof box or safe deposit box for } \\
\text { currently owned properties, filing cabin } \\
\text { for previously owned properties }\end{array}$ \\
\hline $\begin{array}{l}\text { Records of outstanding debts, notes, or } \\
\text { mortgages and names and addresses of } \\
\text { lenders }\end{array}$ & Permanently or as long as needed & Fireproof Box or Safe Deposit Box \\
\hline \multicolumn{3}{|c|}{ PERSONAL DOCUMENTS } \\
\hline Type of Record & How long to keep & Where to Keep Them \\
\hline $\begin{array}{c}\text { Certificates of Birth, Death, Marriage, } \\
\text { or Divorce }\end{array}$ & Permanently & Fireproof Box or Safe Deposit Box \\
\hline $\begin{array}{c}\text { Names, addresses, and phone numbers } \\
\text { of financial, business, personal, and } \\
\text { legal advisors. }\end{array}$ & Permanently & Fireproof Box or Safe Deposit Box \\
\hline Social Security Papers & Permanently & Fireproof Box or Safe Deposit Box \\
\hline Passports & Until They Expire & Fireproof Box or Safe Deposit Box \\
\hline $\begin{array}{c}\text { Copies of critical letters: letters of } \\
\text { appointment or resignation; legal } \\
\text { notifications. }\end{array}$ & Permanently or as long as needed & $\begin{array}{c}\text { Fireproof Box, Safe Deposit Box, or } \\
\text { Filing Cabinet, depending on } \\
\text { importance. }\end{array}$ \\
\hline
\end{tabular}

*Portions of this table have been adapted from the "Financial Records Timeline" found
at http://www.bankrate.com/brm/news/mtg/20000518h.asp 